\title{
Ecology of Tengkawang Forests under Varying Degrees of Management in West Kalimantan
}

\author{
Eizi SUZUKI, Mitsuru HOTTA Faculty of Science, Kagoshima University, Kagoshima 890, Japan \\ Tukirin PARTOMIHARDJO Research and Development Center for Biology, LIPI, Bogor, Indonesia. \\ Achmad SULE \\ Fumito KOIKE \\ Naohiko NOMA \\ Toshihiro YAMADA \\ Mikio KAJI \\ Research and Development Center for Geotechnology, LIPI, Bandung, Indonesia. \\ Faculty of Life \& Environmental Science, Shimane University, Matsue 690, Japan \\ Center for Ecological Research, Kyoto University, Sakyo, Kyoto 606-01, Japan \\ Faculty of Science, Osaka City University, Sumiyoshiku, Osaka 558, Japan \\ University Forest in Hokkaido, Faculty of Agriculture, University of Tokyo, \\ Furano Hokkaido 079-15, Japan
}

\begin{abstract}
West Kalimantan has about 10 species of Shorea called as tengkawang whose fruits are economically useful as source of fat. The fruits were collected from natural and semi-natural forests and plantations. We made eight plots in tengkawang forests in 1991 to study the change of forests by the human activity. In Ngabang which had been the capital city of old Landak Kingdom, the king made two plantations of ca. $1 \mathrm{~km}^{2}$ about 100 year ago. In tengkawang species, $S$. stenoptera was mainly planted on flat bank near river, and $S$. amplexicaulis, and $S$. pinanga was on upper slope. They reached $125 \mathrm{~cm}$ in DBH and $49 \mathrm{~m}$ in height. The average diameter increment of tengkawang from 1991 to 1994 was $0.28( \pm 0.32$ SD) $\mathrm{cm} / \mathrm{yr}$. Two rubber tree species, Hevea brasiliensis and Palaquium gutta were planted under the canopy of tengkawangs of flat bank and slope, respectively. The plot had 123 species of wild and cultivated trees $(\mathrm{DBH}>4.8 \mathrm{~cm})$ in 1 ha, and the diversity was similar to the natural tengkawang forest.

On river banks of small stream near a village Muarailai, semi-natural tengkawang forests were found. Large trees reached $186 \mathrm{~cm}$ in DBH. People had cut useless trees and planted useful trees such as Hevea and Durio under the canopy of tengkawang. Along the Daid River, tengkawang forest remained nearly natural condition. The forest structure was similar to semi-natural forest but no planted trees except one escaped shrub Bullucia pentamera introduced from Latin America. The common tengkawang, S. stenoptera dominated exclusively on flat river banks of sandy soil and the diversity was not so high. The other dipterocarp forest on slope had higher diversity.
\end{abstract}

Key Words: tropical rain forest / Kalimantan / Tengkawang / illipe nuts / plantation / biodiversity

Dipterocarp forests on lowland of Borneo Island have the richest tree flora in the world. The Dipterocarpaceae has 267 species on this Island of 746,305 km² (Ashton, 1982). The fruit have a variety in size and shape, and some one dispersed by gyration (or wind), non-gyration, and by water (Suzuki \& Ashton, 1996). The fruit has many fat and is edible for human and wild animals. Fruits of 13 species, called as tengkawang, are of commercial significance to produce fat, and the dried illipe nuts were exported from Sarawak as early as 1908 (Soon, 1988). In West Kalimantan, there are about 10 species of tengkawang. Tengkawang produces illipe nuts of 10,640 ton in 1983 in West Kalimantan (Suzuki \& Gadrinab, 1988). They were used to make fat at a factory in Pontianak, and the fat was exported to Japan etc. But the fruit production fluctuates greatly, and there were no fruits in 1984. De Vriese traveled in West Kalimantan from October 1860 to early of 1861 (De Vriese, 1861; Van Steenis-Kruseman, 1948-1954), and found at first the tengkawang species: Shorea splendida (De Vriese) Ashton, S. stenoptera Burck, and S. seminis (De Vriese) Slooten. Tengkawang forests distribute naturally in Borneo, but some of them near villages might be affected by human activities 


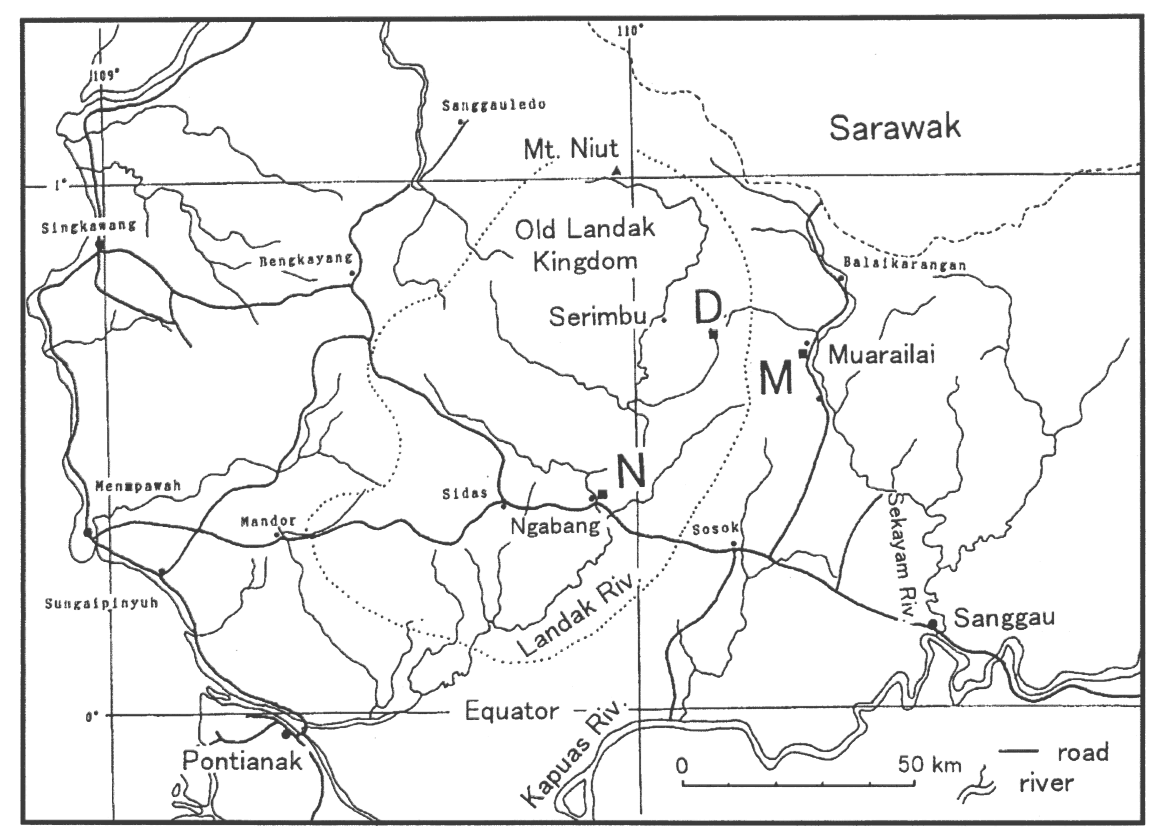

Fig. 1. Map of study site. N, M, and D show the location of plots, in Ngabang (N-1 to -5), Muarailai (M-1 to -3 ), and Daid (D-1 to -4$)$. Dot line shows the boundary of old Landak Kingdom.

Table 1. Precipitation and temperature.

\begin{tabular}{|c|c|c|c|c|c|c|c|c|c|c|c|c|c|}
\hline Site(measured years) & Alt. Lat. & Long. & Annual & Jan & Feb & Mar Apr & May & Jun & Jul & $\mathrm{Aug}$ & Sep & Oct No & Dec \\
\hline \multicolumn{14}{|c|}{ Rain fall (mm/month) } \\
\hline Pontianak (1968-1991) & $3 \mathrm{~m} 0^{\circ} 09^{\prime} \mathrm{S}$ & $109^{\circ} 20^{\prime} \mathrm{E}$ & 3302 & 266 & 185 & 263287 & 287 & 227 & 208 & 200 & 305 & 352 & 310 \\
\hline Ngabang (1931-1960) & $10 \mathrm{~m} 0^{\circ} 23^{\prime} \mathrm{N}$ & J $109^{\circ} 57^{\prime} E$ & 2969 & 281 & 231 & 267270 & 240 & 173 & 184 & 186 & 244 & 273 & 290 \\
\hline Sanggau (1950-1991) & $10 \mathrm{~m} 0^{\circ} 08^{\prime} \mathrm{N}$ & J $110^{\circ} 36^{\prime} \mathrm{E}$ & 3060 & 304 & 273 & 281266 & 256 & 169 & 204 & 198 & 214 & 278 & 310 \\
\hline Serimbu (1986-1994) & $80 \mathrm{~m}^{\circ} 45^{\prime} \mathrm{N}$ & J $110^{\circ} 06^{\prime} \mathrm{E}$ & 4470 & 461 & 254 & 503425 & 351 & 255 & 284 & 251 & 301 & 409 & 487 \\
\hline \multicolumn{14}{|l|}{ Temperature $\left({ }^{\circ} \mathrm{C}\right)$} \\
\hline Pontianak (1973-1991) & $3 \mathrm{~m} 0^{\circ} 09^{\prime} \mathrm{S}$ & $109^{\circ} 20^{\prime} \mathrm{E}$ & 26.3 & 25.9 & 26.2 & 26.426 .4 & 26.8 & 26.8 & 26.3 & 26.5 & 26.4 & 26.226 .0 & 25.9 \\
\hline
\end{tabular}

\footnotetext{
Data source: Ngabang from Sastrodimedjo et al. 1974, and others are from unpublished data of each station: Stasium Meteorologi Pontianak, Dinas Pertanian at Sanggau, and district office at Serimbu.
}

such as selective cutting of useless trees, and planting of tengkawang in a small scale. S. stenoptera and $S$. seminis prefer the river banks, which are also suitable sites to establish villages. After starting the export of illipe nuts to Europe, plantation of tengkawangs have been made. A few of the plantations are now about 100 years old. In tropical areas, such old plantations were rarely found. Thus we can find now many forests in varying degrees of management; natural forests, semi-natural forests (the tengkawang grew naturally but the forest structure changed by human use), and pure plantations. Our purpose of study is to compare the forests among them and to detect the change of forest by human activity. These kinds of forests are interesting and useful for investigating the effect of human on the forests. The study will give us basic knowledge how to manage the forests.

Because illipe nuts are one of the most important forest products in West Kalimantan, several studies have been made. More than hundred years ago, the importance of tengkawang fat was reported (De Vriese, 1861; Burck, 1886). The pilot plantation of tengkawang started in 1940 at Haurbentes, Bogor (Departmen Kehutanan, 1990). Suzuki \& Gadrinab (1988) have studied the fruit production in a young plantation of tengkawang. Watanabe (1996) described the economical use of illipe nuts. But the purpose of most researches are the economical uses of tengkawang, and the forests have rarely 
studied from ecological view points.

\section{STUDY SITE AND METHODS}

\section{Study site}

We studied tengkawang forests at three sites in West Kalimantan: Ngabang, Muarailai, and Daid (Fig. 1). Table 1 shows precipitation and temperature at sites around the study area. Annual mean temperature was $26.3^{\circ} \mathrm{C}$ and the difference between maximum and minimum of monthly mean temperatures was $0.9^{\circ} \mathrm{C}$ at Pontianak, a city on the equatorial line. February, June, July and August are rather dry but these months still have precipitation more than $160 \mathrm{~mm} / \mathrm{month}$. Annual precipitations at four sites were from $2969 \mathrm{~mm} / \mathrm{yr}$ to $4470 \mathrm{~mm} / \mathrm{yr}$.

\section{Vegetation survey}

We made eight plots from end of July until early of October, 1991. The description of the location, and size of plots is shown in Table 2. One plot of $250 \mathrm{~m} \times 50 \mathrm{~m}$ was made in an plantations of tengkawang about 100 years old in Ngabang. The plot was divided into 5 subplots of $50 \mathrm{~m} \times 50 \mathrm{~m}$, $\mathrm{N}-1$ to N-5 from land side to riverside (Fig. 2.c). In two adjacent villages, Muarailai and Muaradua, we made three plots (M-1, M-2, and M-3). M-1 was in a private plantation about 20 years old. M-2 and M-3 were in semi-natural stands along a small stream in Muarailai. We made four plots ( D-1 to D-4) in tengkawang and dipterocarp forests along the Daid River which is the boundary of Kecamatan (district) Serimbu, Kabupaten (prefecture) Pontianak, and Kecamatan Beduai, Kabupaten Sanggau. Forests in this area have been logged since 1984 by a logging company, P. T. Batasan. Many people are entering there through the logging roads and making shifting cultivation. Before the logging there were no roads, and local people usually used rivers for transportation.

The plots were divided into $10 \mathrm{~m} \times 10 \mathrm{~m}$ subplots. The heights of the ground were measured along the grids, and contoured maps were made. Number tags of aluminum or plastic were put on all trees bigger than $15 \mathrm{~cm}$ in girth at the height of $1.3 \mathrm{~m}$ above the ground (GBH). The GBH were measured for the tagged trees with a steel measure. In November 1993, the GBHs of trees in N-1 N-5, D-1, and D-4 were remeasured, and in November 1995, those in N-1 N-4 were remeasured at the third time. In 1991, the herbarium specimens were collected from them except some big trees and trees easily identified. In some plots the location of trees and height of trees were measured. Forest profile of trees bigger than $10 \mathrm{~cm}$ in diameter at the height of $1.3 \mathrm{~m}$ above the ground (DBH) were drawn in a belt of $10 \mathrm{~m}$ width. For Shorea stenoptera, all individuals in the plots were measured for DBH, if exist, height and the location. Height of tengkawang trees in Plot $\mathrm{N}$ was measured. For tengkawang species, the seedlings and saplings smaller than $15 \mathrm{~cm}$ in $\mathrm{GBH}$ were tagged and measured by their height and locations in N-1 to N-4 and D-1 to D-3 in 1991, and remeasured in N-1 to N-4 and D-1 in 1993.

\section{Soil analysis}

The soil augering was carried out in at every corners of $10 \mathrm{~m} \times 10 \mathrm{~m}$ subplots of D-1, D-2 and D-3 in August 1991. Eight pedons were examined in the fresh pits, and 34 soil samples were collected for physical and chemical analysis. The analyses were as follow: 1) particle size distribution (clay of less than $0.002 \mathrm{~mm}$, silt of less than $0.05 \mathrm{~mm}$ and sand) by sedimentation method after the decomposition of organic matter with $\mathrm{H}_{2} \mathrm{O}_{2}$, 2) total carbon by Kurmis's method, 3) total nitrogen by Kjeldal's method, 4) $\mathrm{pH}$ in water and in $1 \mathrm{~N} \mathrm{HCl}$ with soil/solution ratio of $1 / 2.5,5$ ) exchangeable bases cation of $\mathrm{Ca}, \mathrm{Mg}, \mathrm{K}$ and $\mathrm{Na}$ in the extracts with $1 \mathrm{~N} \mathrm{CH}_{3} \mathrm{COONH}_{4}(\mathrm{pH}=7)$ and water by the method of 
Table 2. Location, size diversity, number of trees, and basal area (BA) of trees in plots. BA $\left(\mathrm{m}^{2} / \mathrm{ha}\right)$ of each species was shown for some useful genera.

\begin{tabular}{|c|c|c|c|c|c|c|c|c|c|c|}
\hline Plot & $\mathrm{N}-1+2$ & $\mathrm{~N}-3+4$ & N-5 & M-1 & M-2 & M-3 & D-3 & D-2 & D-1 & D-4 \\
\hline Lat. (N) & $0^{\circ} 23^{\prime}$ & $0^{\circ} 23^{\prime}$ & $0^{\circ} 23^{\prime}$ & $0^{\circ} 40^{\prime}$ & $0^{\circ} 40^{\prime}$ & $0^{\circ} 40^{\prime}$ & $0^{\circ} 43^{\prime}$ & $0^{\circ} 43^{\prime}$ & $0^{\circ} 43^{\prime}$ & $0^{\circ} 43^{\prime}$ \\
\hline Long. (E) & $109^{\circ} 57^{\prime}$ & $109^{\circ} 57^{\prime}$ & $109^{\circ} 57^{\prime}$ & $110^{\circ} 22^{\prime}$ & $110^{\circ} 22^{\prime}$ & $110^{\circ} 22^{\prime}$ & $110^{\circ} 12^{\prime}$ & $110^{\circ} 12^{\prime}$ & $110^{\circ} 12^{\prime}$ & $110^{\circ} 12^{\prime}$ \\
\hline Alt. (m) & 30 & 10 & 10 & 50 & 50 & 50 & 60 & 60 & 60 & 100 \\
\hline Area $\left(\mathrm{m}^{2}\right)$ & 5000 & 5000 & 2500 & 300 & 2732 & 2400 & 4528 & 3133 & 7480 & 5000 \\
\hline Fisher's $\alpha$ & 41.2 & 20.8 & 8.7 & 2.7 & 27.3 & 43.3 & 42.1 & 81.9 & 183.9 & 174.4 \\
\hline Morisita's $\beta$ & 13.9 & 6.8 & 12.2 & 3.8 & 9.4 & 18.5 & 14.3 & 60.9 & 112.8 & 139.0 \\
\hline $\mathrm{H}^{\prime}(\mathrm{No})$ & 5.1 & 4.1 & 3.9 & 2.1 & 4.5 & 5.2 & 4.9 & 6.0 & 7.6 & 7.7 \\
\hline $\mathrm{H}^{\prime}(\mathrm{BA})$ & 2.6 & 1.1 & 3.5 & 1.0 & 2.0 & 1.8 & 1.3 & 2.3 & 6.6 & 6.0 \\
\hline No. of trees & 412 & 222 & 138 & 52 & 179 & 145 & 306 & 272 & 1074 & 1038 \\
\hline No. of identified trees & 404 & 220 & 129 & 51 & 177 & 138 & 253 & 141 & 953 & 950 \\
\hline No. of all species & 98 & 51 & 24 & 8 & 55 & 62 & 82 & 82 & 335 & 325 \\
\hline No. of dipterocarp species & 5 & 2 & 1 & 1 & 2 & 2 & 3 & 5 & 16 & 18 \\
\hline Total BA $\left(\mathrm{m}^{2} / \mathrm{ha}\right)$ & 44.23 & 35.49 & 21.22 & 42.01 & 48.39 & 41.34 & 34.32 & 31.12 & 26.33 & 54.90 \\
\hline \multicolumn{11}{|l|}{ BA of each species } \\
\hline Shorea stenoptera & 6.92 & 30.19 & 0.10 & 32.97 & 37.15 & 30.68 & 27.60 & 8.50 & 3.00 & \\
\hline S. amplexicaulis & 21.20 & & & & & & & & & \\
\hline S. cf. amplexicaulis & & & & & & & & & & 0.21 \\
\hline S. pilosa & & 0.00 & & & & & & & & \\
\hline S. pinanga? & 3.90 & 0.38 & & & & & & & 0.02 & \\
\hline S. seminis & & & & & 0.43 & 0.04 & 0.03 & 0.28 & & \\
\hline Shorea sp.(Labe) & 0.67 & & & & & & & & & \\
\hline Other dipterocarps & & & & & & & 0.09 & 0.24 & 3.04 & 18.40 \\
\hline Hevea brasiliensis ${ }^{*+}$ & 0.29 & 1.84 & 1.97 & 6.44 & 1.40 & 0.05 & & & & \\
\hline Durio ziebethinus & 0.19 & 0.76 & & & 0.03 & 0.08 & 0.01 & & & \\
\hline D. kutejensis & & & & & 1.02 & 0.05 & & & 0.02 & 0.26 \\
\hline D. griffithii & & & & & & & & & 0.05 & \\
\hline Eusideroxylon zwageri & & 0.39 & & & & & 0.02 & 0.02 & 0.02 & \\
\hline Bullucia pentamera ${ }^{+}$ & 0.004 & & & & & & 0.35 & 0.01 & 0.13 & \\
\hline Lansium domesticum & 0.01 & 0.24 & & & 0.16 & 0.29 & & & & \\
\hline Artocarpus integer ${ }^{\star}$ & 0.33 & 0.12 & & & 0.07 & 0.12 & & & & 0.07 \\
\hline A. anisophyllus & 0.01 & & & & 0.59 & 0.19 & & 0.01 & 0.04 & 0.01 \\
\hline A. dadah & & & & & & & & & 0.01 & \\
\hline A. elasticus & & & & 0.07 & 1.87 & 0.14 & 0.04 & & & 0.12 \\
\hline A. cf. glaucus & 0.00 & 0.01 & & & 0.02 & & 0.01 & & & \\
\hline A. kemando & & 0.02 & & & & 0.26 & & & & \\
\hline A. rigidus & & & & & 0.29 & & & & & 0.06 \\
\hline A. rotunda & 0.02 & & & & & & & & & \\
\hline A. cf. tamaran & & & 0.21 & & & 0.11 & & & & \\
\hline Nephelium lappaceum & & 0.06 & & & 0.10 & 0.03 & & 0.02 & & \\
\hline N. maingayi? & & & & & 0.01 & & & & & \\
\hline N. ramboutan-ake? & & & & & & & & & & 0.06 \\
\hline N. reticulatum & & & & & & & & & 0.01 & \\
\hline N. uncinatum & & & & & & & 0.03 & 0.02 & 0.00 & \\
\hline Palaquium gutta* & 6.25 & 0.01 & & & & & & & & \\
\hline$P$. (small leaf) & & & & & & & & & & 0.01 \\
\hline P. calophyllum & & & & & 0.03 & 0.09 & & 0.02 & 0.14 & 0.46 \\
\hline P. dasyphyllum & & & & & & 0.01 & & & & \\
\hline P. majes & & & & & & & 0.01 & & 0.00 & 0.05 \\
\hline P. cf. oxleyanum & & & & & & & & & & 0.14 \\
\hline P. rostratum? & & & & & & & & & & 0.01 \\
\hline
\end{tabular}

+ introduced from tropical America. ${ }^{*}$ planted.

atomic absorption spectrophotometry, 6) cation exchange capacity (CEC) determined by the saturation with $1 \mathrm{~N} \mathrm{CH}_{3} \mathrm{COONH}_{4}(\mathrm{pH}=7)$, followed by the ethanol washings and the replacement of absorbed $\mathrm{NH}_{4}{ }^{+}$with $1 \mathrm{~N} \mathrm{NaCl}$, and measurement of $\mathrm{NH}_{4}$ amount by spectrophotometer using Nesslers solution, and 7) available potassium and phosphorus determined by Olsen's method. 


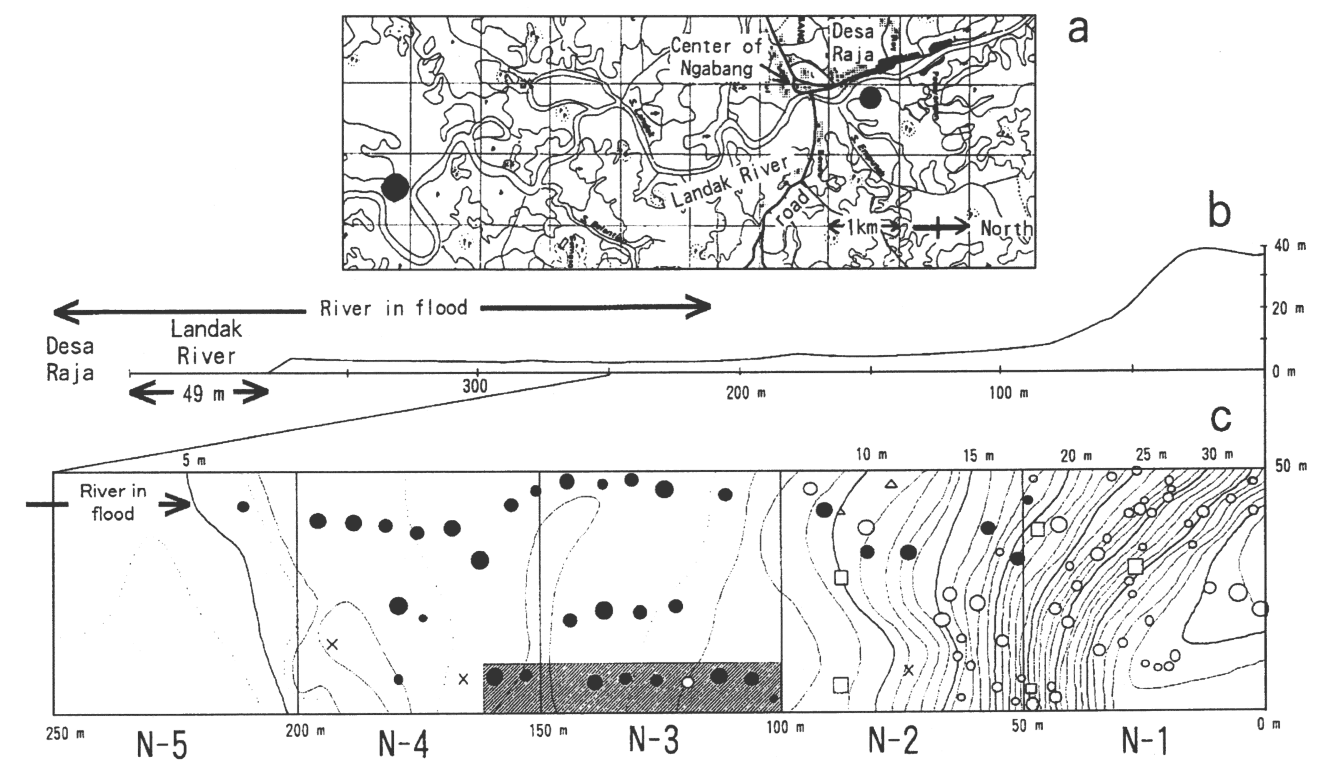

Fig. 2. Location of trees in Ngabang. a: map around Ngabang with two solid circles showing tengkawang plantations. Plot $\mathrm{N}-1$ to -5 were made in the plantation near Desa raja. b: topography from the Landak River to plot. c: contour maps of the plot. Solid contours are at $1 \mathrm{~m}$ interval and contours of broken line at $0.5 \mathrm{~m}$ interval are added in flat area. $:$ S. stenoptera. $\square:$ S. pinanga. $\triangle:$ Shorea $\mathrm{sp} . \times:$ dead Shorea. The symbol size shows the tree size.

\section{RESULTS}

\section{Old plantation at Ngabang}

There were old plantations of tengkawang established about 100 years ago in Ngabang (Fig. 1 and Fig. 2). The city is the center of Ngabang Districts (Kecamatan), and was the capital of old Landak Kingdom which had been established as an Islam kingdom late in the fifteenth century and under the control of colonial government of Dutch in the nineteenth century (Team Penyusun Monografi Daerah Kalimantan Barat, 1976). The Kingdom had covered about four districts (Kecamatan) of today: Ngabang, Serimbu, Daid, and Pahauman. The owner of the plantation, Mr. Gusti Basuni Bdr. who was born in 1928 at Desa Raja (village of king) in Ngabang as the son of the last king, and died in 1995. According to him, his grandfather made the plantation about 100 years ago. The source of planted fruits had been originally brought from the upper part of the Landak River, where we made other plots as mentioned later. Around Ngabang there are no tengkawang trees except the plantations though it is a common tree in Sanggau, one of the main area of illipe nuts production (Soon, 1988). In Kalimantan, tengkawang trees do not distribute in coastal area (Sumadiwangsa, 1977). Tengkawang trees were rare between Pontianak and Ngabang except Shorea macrophylla (De Vriese) Ashton at Mandor (Fig. 1). Though illipe nuts had been collected by local people to make food fat for their home use from old time, the plantations were made to export the dried fruit to Europe. One plantation of about 100 ha was $1 \mathrm{~km}$ north of center of Ngabang and between the Landak River and a small stream, Emputeh (Fig. 2.a ). Desa Raja and the plantation is opposite site of the Landak River. $S$. stenoptera (tengkawang tungkul) and $S$. amplexicaulis (tengkawang meje) were mainly planted though many tengkawang species were additionally planted such as Shorea macrophylla, $S$. beccariana Burck, S. mecistopterix Ridley, S. pilosa Ashton, and S. pinanga Scheff. Another plantation was along the Landak River about $7 \mathrm{~km}$ south of center of Ngabang. It was larger than 100 


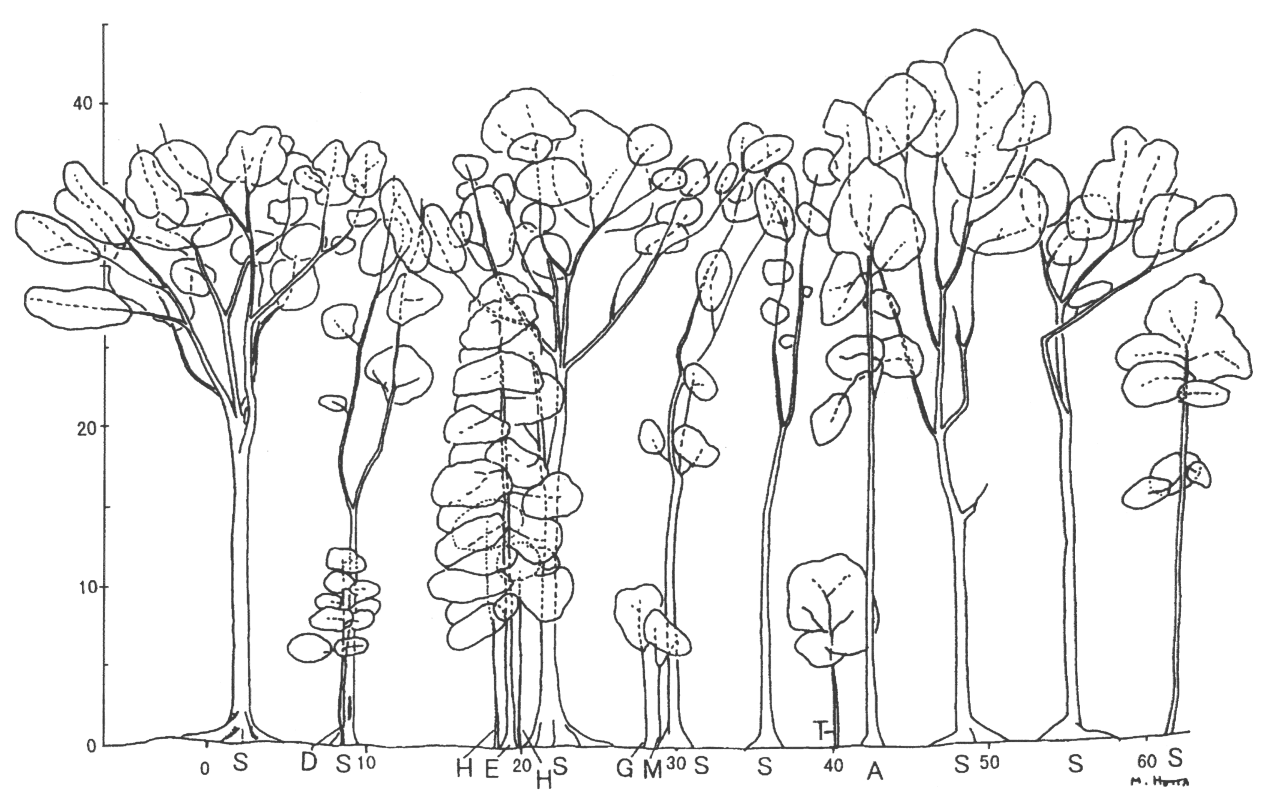

Fig. 3. Profile of trees in shadowed part of N-4 and N-3 of Fig. 2. S, Shorea stenoptera; A, Shorea amplexicaulis; T, Tabernaemontana (K3024); G, Gardenia forsteriana; M Macaranga depressa forma strigosa; E, Eusideroxylon zwageri; H, Hevea brasiliensis; D, Dillenia cf. borneensis.

ha, and there are many Shorea amplexicaulis, S. pinanga and S. mecistopteryx but fewer S. stenoptera.

Figure 2.b shows the topography between the Landak River and the plantation. The river was 49 $\mathrm{m}$ in width at usual water level. But floods of the river, which occurred almost every year and continued for several days, raised the water level about four meters, and the forest between river and the point of arrow in Fig. 2.b was inundated. The plot at Ngabang was $250 \mathrm{~m} \times 50 \mathrm{~m}$, and $4 \mathrm{~m}$ to 42 $\mathrm{m}$ higher than the usual water level. It was divided into five subplots of $50 \mathrm{~m} \times 50 \mathrm{~m}$ from N-1 to N5. Most part of $\mathrm{N}-1$ was lower than $6 \mathrm{~m}$ in height inundated periodically, and tengkawang trees were not distributed. The upper flat area $(\mathrm{N} 3+4)$ was higher than the water level by six or more meter and was rarely waterlogged. S. stenoptera had been planted in three rows in this area. S. amplexicaulis was planted on the slope $(\mathrm{N}-1+2)$ most frequently, though the original rows of plantation were unclear because of vigorous regeneration of small trees.

Figure 3 shows the forest profile in the shadowed part of $10 \mathrm{~m} \times 60 \mathrm{~m}$ of Fig. 2c, where was flat and dominated by $S$. stenoptera. This species has large leaves and thick branches. The crown had a rather flat top and was not dome-shaped as usual emergent trees of Shorea. The tallest tree in this plot was $S$. amplexicaulis of $49 \mathrm{~m}$ in height, and tallest $S$. stenoptera was $44 \mathrm{~m}$. Tengkawang trees made a continuous canopy layer from $35 \mathrm{~m}$ to $45 \mathrm{~m}$ in height, and no emergent trees. The largest tree in DBH was $125 \mathrm{~cm}$ in S. stenoptera, and $117 \mathrm{~cm}$ in S. amplexicaulis. Trees distribute sparsely under the canopy because useless trees were often cut.

Fig. 4 shows the DBH distributions of main species in three parts of plot $\mathrm{N}$ : slope part $(\mathrm{N}-1+2)$, flat part $(\mathrm{N}-3+4)$, and flat and low part $(\mathrm{N}-5)$. Table 2 shows the basal area of tengkawang species and other useful genera. The subplot nearest the river, N-5 of $50 \mathrm{~m} \times 50 \mathrm{~m}$ part, was a secondary forest dominated by Largerstroemia speciosa (L.) Pers. People often use this forest to get wood for fuel and light construction. This area is covered with water at flood, and tengkawang was not planted here. Most of $S$. stenoptera were planted on flat part of N-3+4. S. amplexicaulis, and $S$. pinanga (tengkawang layar) were on the slope of $\mathrm{N}-1+2$. As shown in the data along the Daid river, the natural 


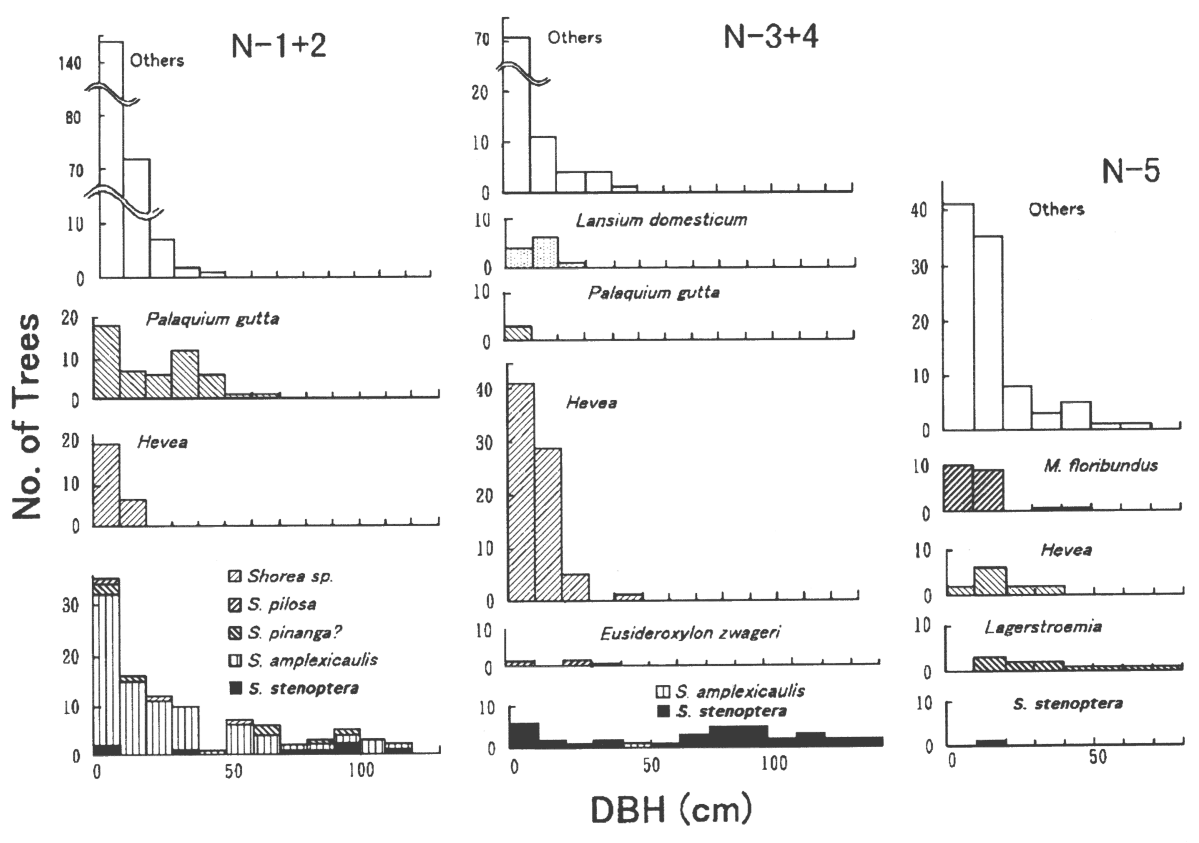

Fig. 4. Frequency distribution of DBH in Ngabang

habitat of S. stenoptera is banks a few meters high along small streams. S. amplexicaulis and $S$. pinanga usually grow on the slope of hills. People seemed to select similar habitats to the natural ones as site of plantation. There were only a few small trees of tengkawang and other species in the flat plain, though many on the slope. Total density of trees (DBH>4.8cm) was $824 / \mathrm{ha}, 444 / \mathrm{ha}$, and 552/ha in slope, flat, and low part, respectively. It might be a result of forest use. People might cut wood more often from flat area and near the river than from the slope. S. stenoptera had much less number of small trees than S. amplexicaulis (Table 3). Because people usually avoided to cut useful tengkawang trees, the poor regeneration of the former might be caused from its regeneration characteristics preferring sunny places for seedling establishment.

In this forest, some other useful trees were added after establishment of plantation, such as latex trees (Palaquium gutta (Hook. f.) Baillon and Hevea brasiliensis Muell. Arg.), wood tree (Eusideroxylon zwageri Teijs. et Bin.), and fruit trees (Durio zibethinus Murr., Lansium domesticum Correa, and Artocarpus integer (Thunb.) Merr.). On the slope, Palaquium gutta had been planted to produce a kind of latex called "gutta percha" in English (Hotta et al. 1989) or "gatah merah (red latex)" in Indonesian. Photograph 1 shows the scar on the trunk to collect the latex many years ago.

Table 3. Number and height $(\mathrm{cm})$ of seedlings and saplings $(\mathrm{GBH}<15 \mathrm{~cm}$ ) of tengkawang in Ngabang (from N-1 to $\mathrm{N}-4), \mathrm{D}-1, \mathrm{D}-2$ and $\mathrm{D}-3$.

\begin{tabular}{llccccrrrr}
\hline \multicolumn{1}{c}{ to $\mathrm{N}-4), \mathrm{D}-1, \mathrm{D}-2$ and D-3. } \\
\multicolumn{1}{c}{$\begin{array}{c}\text { In } 1991 \\
\text { Species }\end{array}$} & $\mathrm{H}<50 \mathrm{~cm}$ & $\mathrm{H}>=50 \mathrm{~cm}$ & Mean H & SD & H<50cm & H>=50cm & Mean H & SD \\
\hline $\mathrm{N}$ & S. amplexicaluis & 198 & 106 & 0.81 & 1.288 & 64 & 141 & 1.11 & 1.481 \\
$\mathrm{~N}$ & S. stenoptera & 13 & 4 & 0.44 & 0.149 & 7 & 8 & 0.69 & 0.336 \\
$\mathrm{~N}$ & Other tengkawang & 76 & 3 & 0.32 & 0.116 & 21 & 28 & 0.55 & 0.213 \\
$\mathrm{D}-1$ & S. stenoptera & 11 & 51 & 1.09 & 0.957 & 2 & 28 & 1.33 & 1.009 \\
$\mathrm{D}-2$ & S. stenoptera & 14 & 112 & 0.91 & 0.687 & - & - & - & - \\
$\mathrm{D}-3$ & S. stenoptera & 16 & 186 & 1.07 & 0.772 & - & - & - & - \\
\hline
\end{tabular}




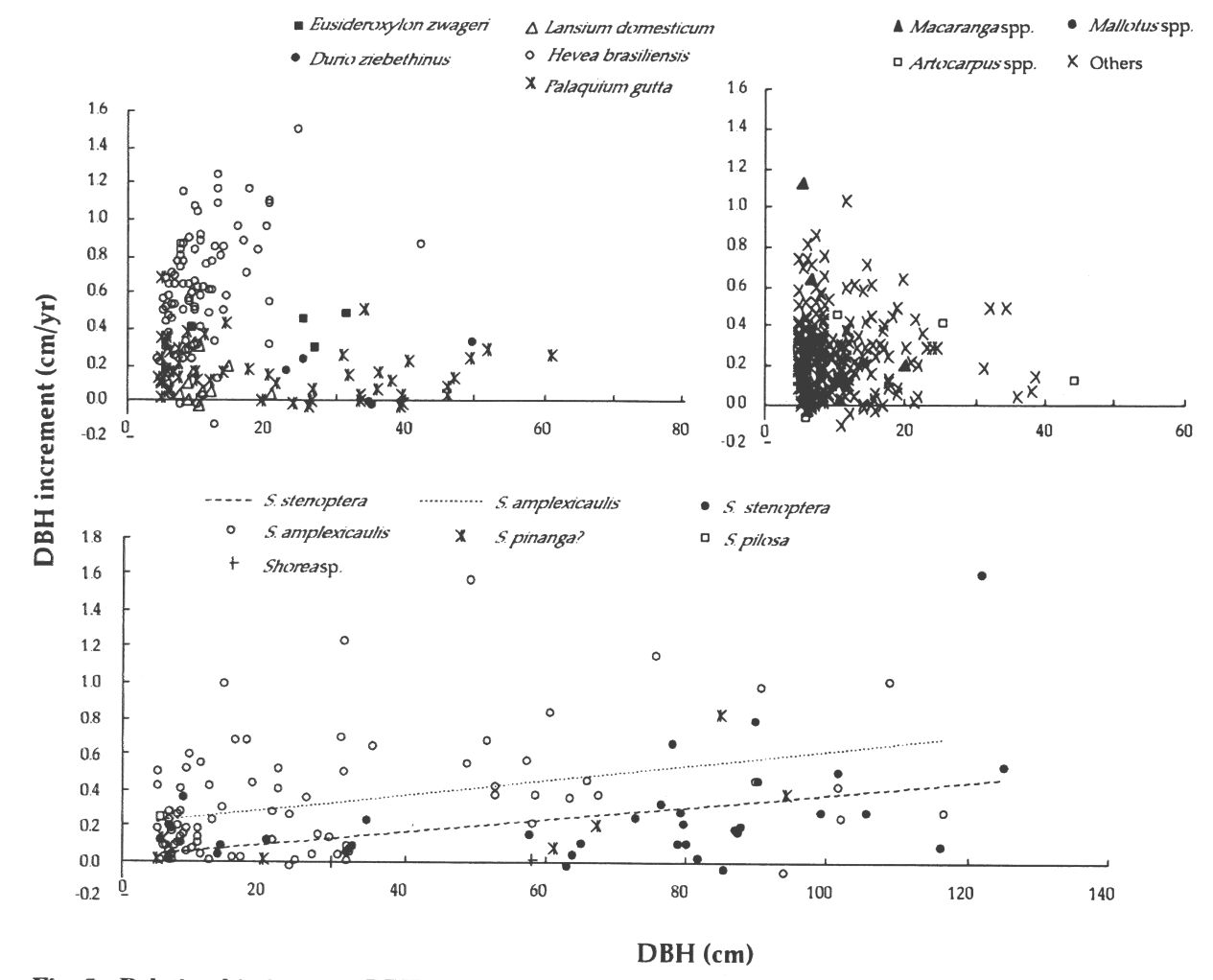

Fig. 5. Relationship between DBH and its increment of trees from N-1 to N-4 for 4.17 years. Dot and broken lines are regressions for Shorea amplexicaulis and S. macrophylla, respectively.

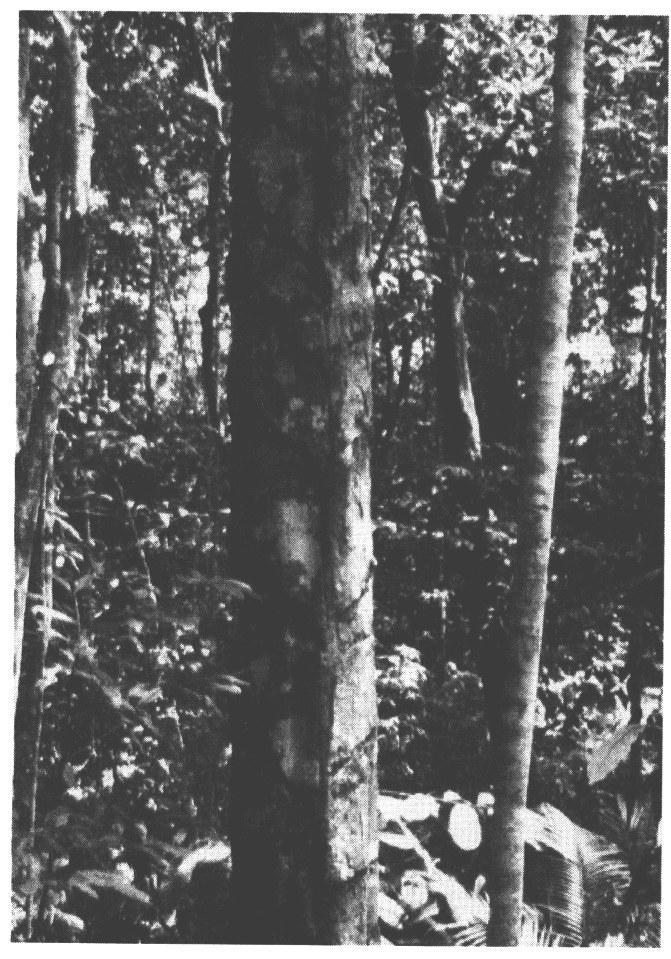

Photograph 1. Scar on a trunk of Palaquium gutta to collect latex in Tengkawang plantation at Ngabang. 


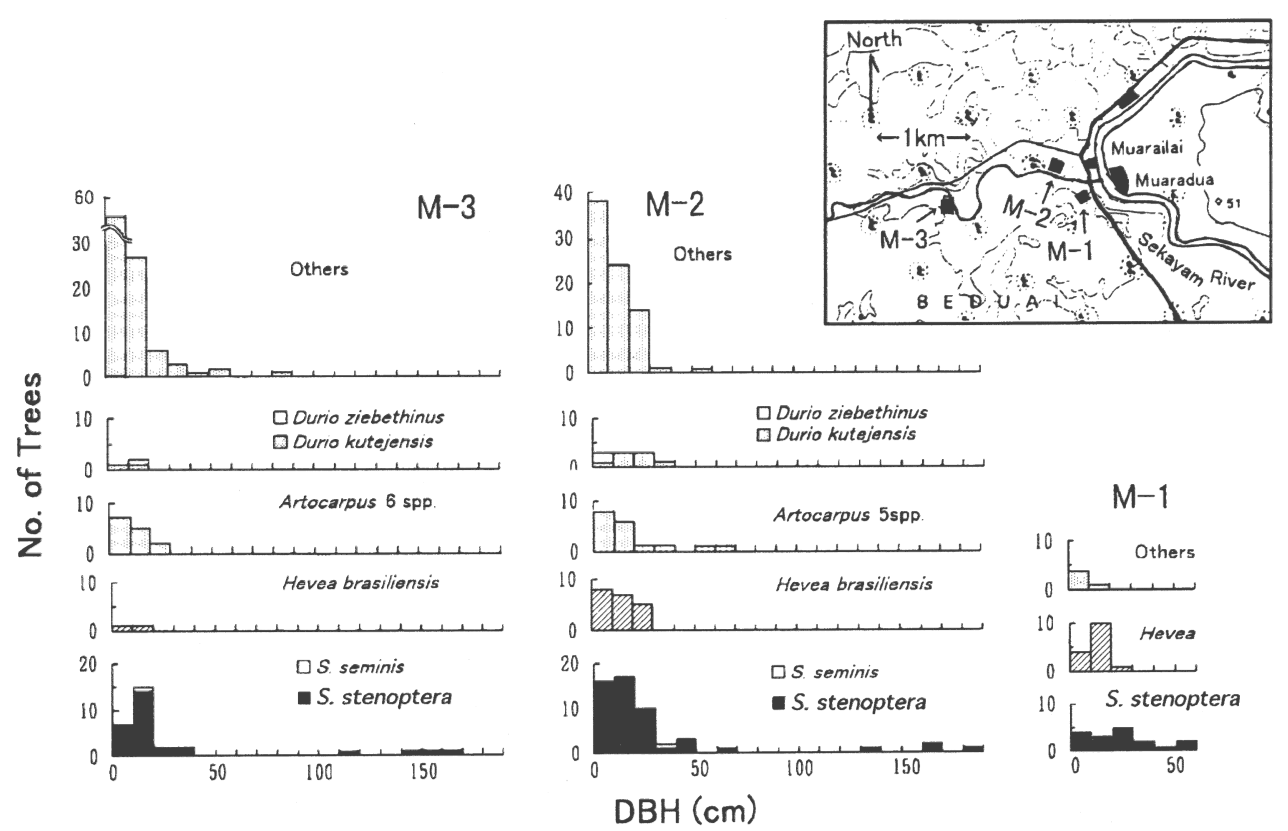

Fig. 6. Frequency distributions of DBH in plots of Muarailai.

Fig. 7. Profile of M-1.

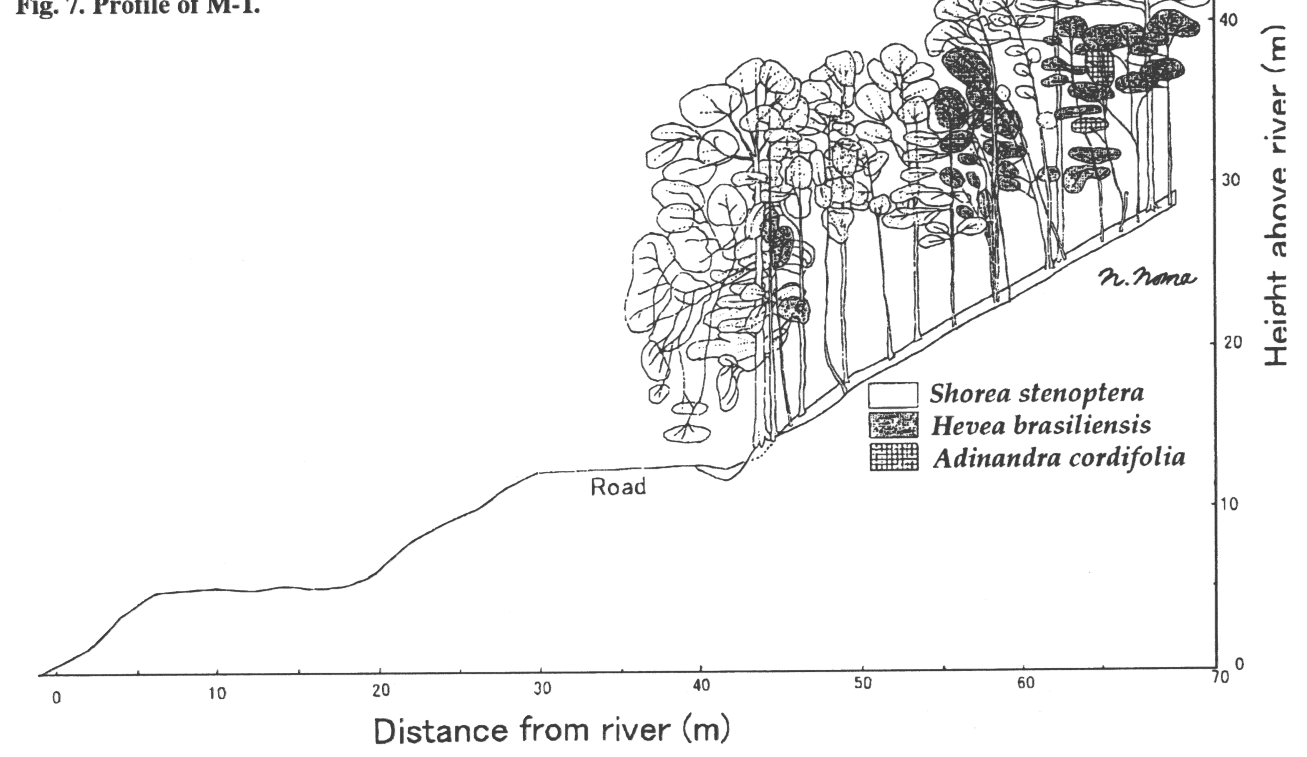

Similar trees of Palaquium with scar of rubber collection were also found in Muarailai. But it has no commercial value now, and is not used. On the flat part, another plant of latex production, Hevea brasiliensis, was planted. Large trees of Hevea are now used to get latex. Many saplings of both species have regenerated naturally. A few trees of Eusideroxylon zwageri were planted but grew slowly. Several fruit trees grew in this plantation. The seeds might be dispersed when people ate the fruit there, and not planted intentionally.

Figure 5 shows the relationship between DBH and its increment $(\mathrm{cm} / \mathrm{yr})$ for observed 4.17 years. 


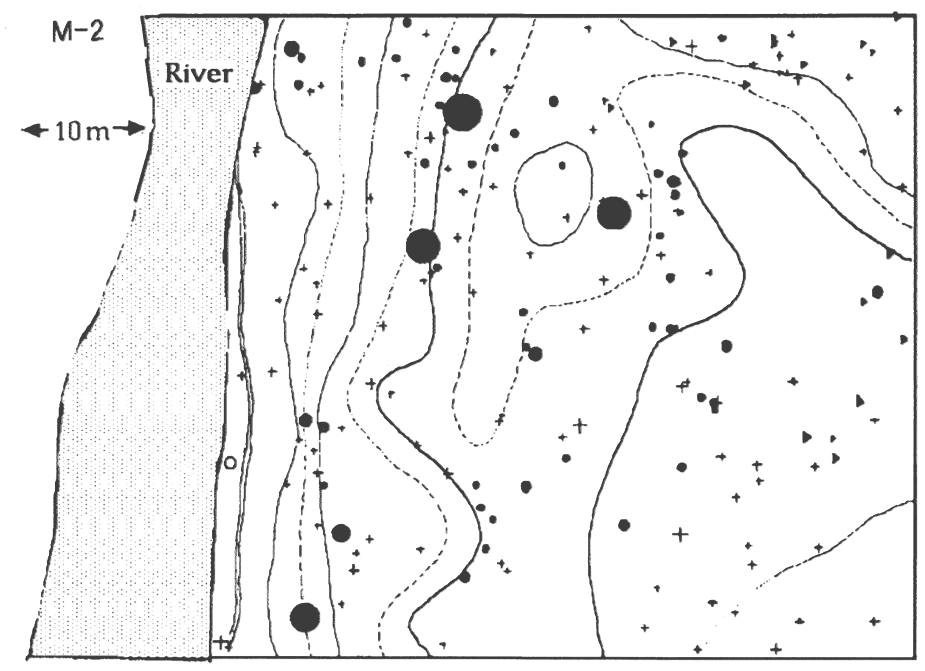

Fig. 8. Topography and location of trees in M-2. Contours of solid and broken line are at $1 \mathrm{~m}$ and $0.5 \mathrm{~m}$ intervals, respectively. $\mathrm{O}$. stenoptera. $\bigcirc:$ S. seminis. $\mathbf{\Delta}$ : Hevea brasiliensis. +: Other species. The symbol size shows the tree size

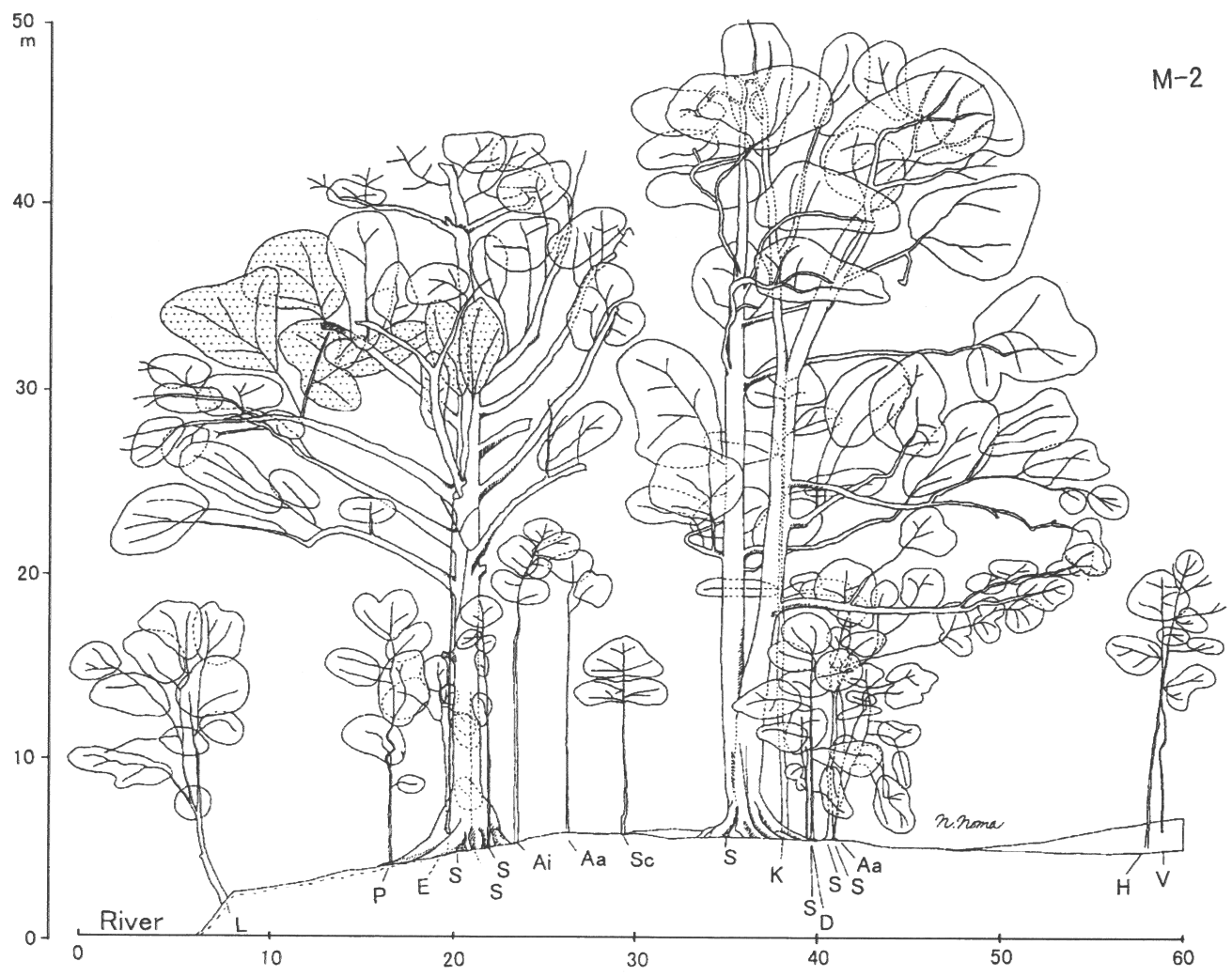

Fig. 9. Profile of M-2. Aa, Artocarpus anisophyllus; Ai, Artocarpus integer; D, Durio kutejensis; E, Eugenia cf. acutangulum H, Hevea brasiliensis; K, Koompassia excelsa; L, Lansium domesticum; P, Pentaspadon motleyi; S, Shorea stenoptera; Sc, Sterculia cf. cordata; V, Vernonia arborea. 
Average increment of 131 tengkawang trees was $0.28( \pm 0.32 \mathrm{SD}) \mathrm{cm} / \mathrm{yr} . S$. stenoptera and $S$. amplexicaulis had a positive correlations: Increment $=0.0035 \mathrm{DBH}+0.01955\left(\mathrm{r}^{2}=0.196\right)$ for the former and, Increment $=0.0042 \mathrm{DBH}+0.1394\left(\mathrm{r}^{2}=0.196\right)$ for the latter as shown in Fig. 5.c. The positive relationships were crude but significant $(\mathrm{P}<0.01)$ though other trees usually tend to have negative relationship. It means that the growth of saplings of tengkawang was suppressed by the canopy trees which were growing well. The sapling of S. stenoptera grew more slowly, and had less number than $S$. amplexicaulis. In other plants, only Hevea had significant relationship $\left(\mathrm{r}^{2}=0.141, \mathrm{P}<0.01\right)$. The increment of some Hevea trees was more than $1 \mathrm{~cm} / \mathrm{yr}$. A few saplings of Macaranga triloba also grew quickly. Average increment of four E. zwageri was $0.41( \pm 0.081 \mathrm{SD}) \mathrm{cm} / \mathrm{yr}$.

\section{Semi-natural forest and plantation in Muarailai and Muaradua}

In two adjacent villages, Muarailai (Kecamatan Beduai) and Muaradua (Kecamatan Kembayan) along the Ilai River, we made three plots (Fig. 6). In this area tengkawang trees seemed to distribute naturally. The villages had established in old time, local people did not know when they had established. They have collected illipe nuts since old time. The Sekayam River is about $50 \mathrm{~m}$ in width at Muarailai. S. stenoptera was mainly distributed along a small branch river, the Ilai River of several meters in width. We made one plot (M-1) in a plantation along the Sekayam River, and two plots (M-2 and M-3) along the Ilai River in 1991.

The plot M-1 was established in a small plantation of about 20 years old by a person in Muaradua. Figure 7 shows the forest profile of M-1 and topography between the river and plot. It was established on a steep slope above the road. The plantation is $40 \mathrm{~m}$ distant from the water of the Sekayam River and $13 \mathrm{~m}$ high from the usual water level. S. stenoptera made a canopy layer of about $20 \mathrm{~m}$ high, and Hevea brasiliensis was made a layer $12 \mathrm{~m}$ high. Figure 6 shows the DBH distribution in M-1. Some trees of S. stenoptera are bigger than $50 \mathrm{~cm}$ in DBH. In one year since our study, most trees in M-1 was cut or burnt to make a rice field of shifting cultivation by the owner. The village seemed to have shortage of land for shifting cultivation, and the fruit of tengkawang seemed not to be more attractive economically than shifting cultivation.

The plot M-2 was made along the Ilai River, $400 \mathrm{~m}$ distant from road along the Sekayam River. The trees of S. stenoptera were separated into two classes of $\mathrm{DBH}$, bigger than $150 \mathrm{~cm}$ and smaller than $70 \mathrm{~cm}$ (Fig. 6). They were apparently older than those in plantation of Ngabang. H. brasiliensis and Durio kutejensis (Hassk.) Becc. were planted. This Durio with red flower and yellow fruits was commoner than usual cultivated Durio zibethinus with creamy white flower around Muarailai. Durio was also found in Daid but different species. Five species of Artocarpus were found in the plot. But they are different species from planted in the garden. A. anisophyllus, and $A$. elasticus were found in this plot and Daid. Wild species of Artocarpus seemed not to be planted but to be protected from cutting because of the edible fruits and useful timber. People felled down many of useless trees or peel the bark to kill. Figure 8 and 9 shows the location of trees and forest profile in M-2, respectively. $S$. stenoptera distributed on river banks from 3 to $5 \mathrm{~m}$ higher than river water. The height is lower than in Ngabang. But the flood water rarely inundated the site of M-2 because the river was smaller than the Landak River at Ngabang. The highest tree in M-2 was $S$. stenoptera of $44.5 \mathrm{~m}$. In M-3, it was also $44 \mathrm{~m}$. The maximum size of $S$. stenoptera seemed to be less than $50 \mathrm{~m}$ in height and $2 \mathrm{~m}$ in $\mathrm{DBH}$, though some Shorea species became taller than $60 \mathrm{~m}$ in this area.

The plot M-3 was made along the Ilai River, $1.5 \mathrm{~km}$ distant from road along the Sekayam River. The topography was similar to that of M-2 and S. stenoptera distributed on the river bank 2-3m higher than the river water. The distribution of DBH was similar to M-2 in S. stenoptera, but Hevea and 


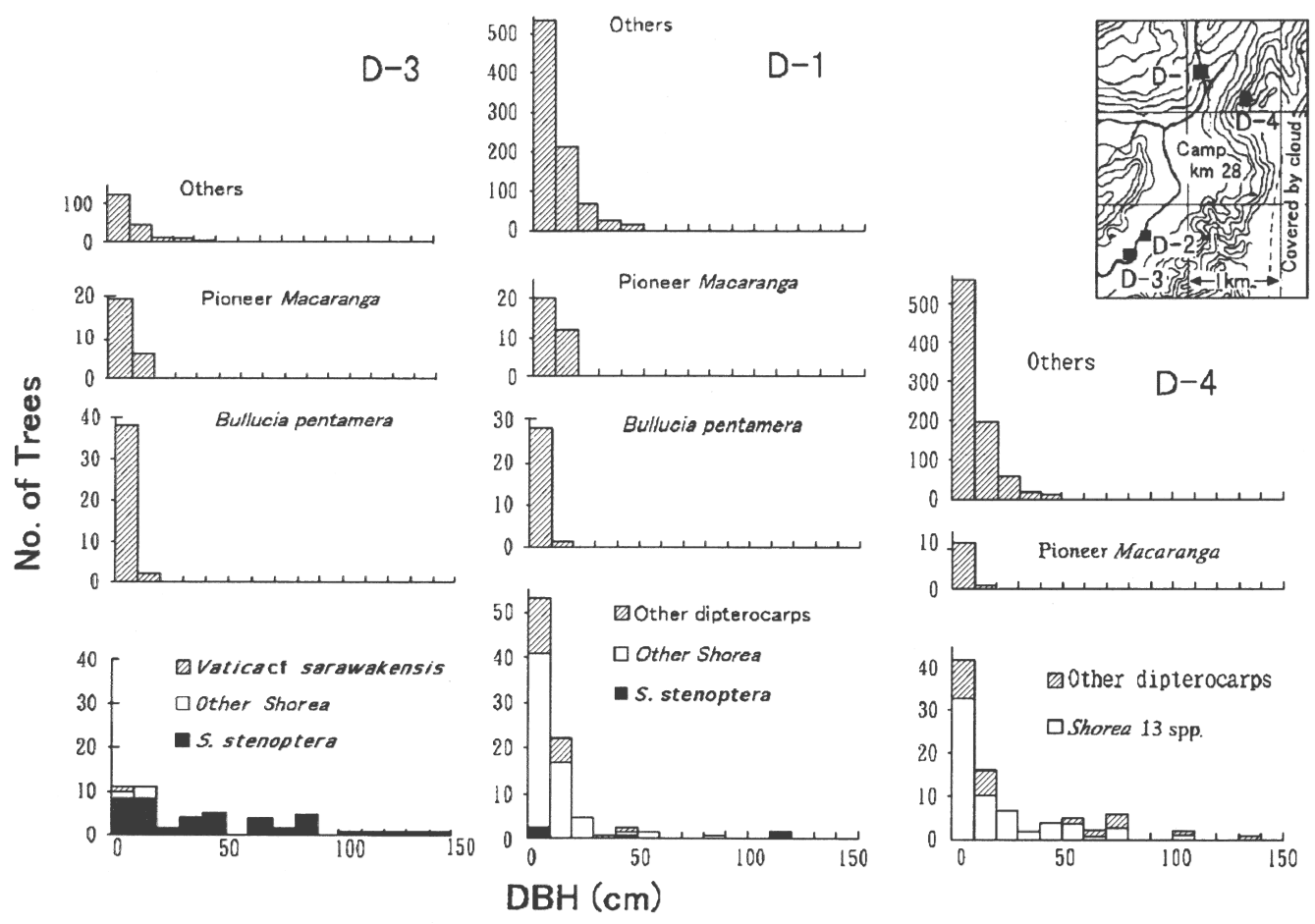

Fig. 10. Frequency distribution of DBH in plots of Daid.

Durio became fewer (Fig. 6). We found many seedlings of S. stenoptera germinated in this year though no seedlings in M-2 where many people collected the fruit, and many domestic pigs fed the fruits.

\section{Natural forests along the Daid River}

Along one of branches of the Landak River, the Daid River, we made plots from D-1 to D-4. D-4 on a steep slope distant $0.5 \mathrm{~km}$ from the river, and other three plots bordered with the river (Fig. 10). The river ran in a little steep valley around D-1, and on a flat plain around D-2 and D-3. Fig. 10 shows the DBH distribution of some representative species and other in D-1, D-3 and D-4.

The topography of D-3 was a flat river bank a few meters higher than the water (Fig. 11). $S$. stenoptera exclusively dominated and occupied $80 \%$ of BA of all species. Because the plot is flat, and left side of the plot has another small stream, S. stenoptera distributed on the whole area of the plot. Fig. 12 shows the forest profile in D-3. S. stenoptera made a continuous canopy about $40 \mathrm{~m}$ high as in M-2 and M-3. The trees in the lower stratum were not so many. As shown in DBH distribution of Fig. 10, S. stenoptera had big trees and also small trees. The small trees gathered in an open area where few big trees existed (Fig. 11). Data of D-2, which was located $60 \mathrm{~m}$ north of D-3, were omitted from the figure because the vegetations in D-2 and D-3 were similar. S. stenoptera was less dominant in D-2 than in D-3. It might be caused that some part of D-2 was steep slope, where other dipterocarps such as $S$. leprosula, S. parvifolia, and S. scaberrima were found.

D-1 was on river sides of Daid, but the topography was steep in most part (Fig. 13). S. stenoptera distributed only in small area of flat bank. The density of seedling and saplings also less than in D-2 and D-3 and they distributed only flat and open area near the river. Instead of low density of $S$. stenoptera, this plot has 16 species of dipterocarps such as, Shorea parvifolia $S$. parvistipulata, $S$. pauciflora, S. scaberrima, S. virescens, Vatica oblongifolia and Hopea dryobalanoides. D-4 was on a 


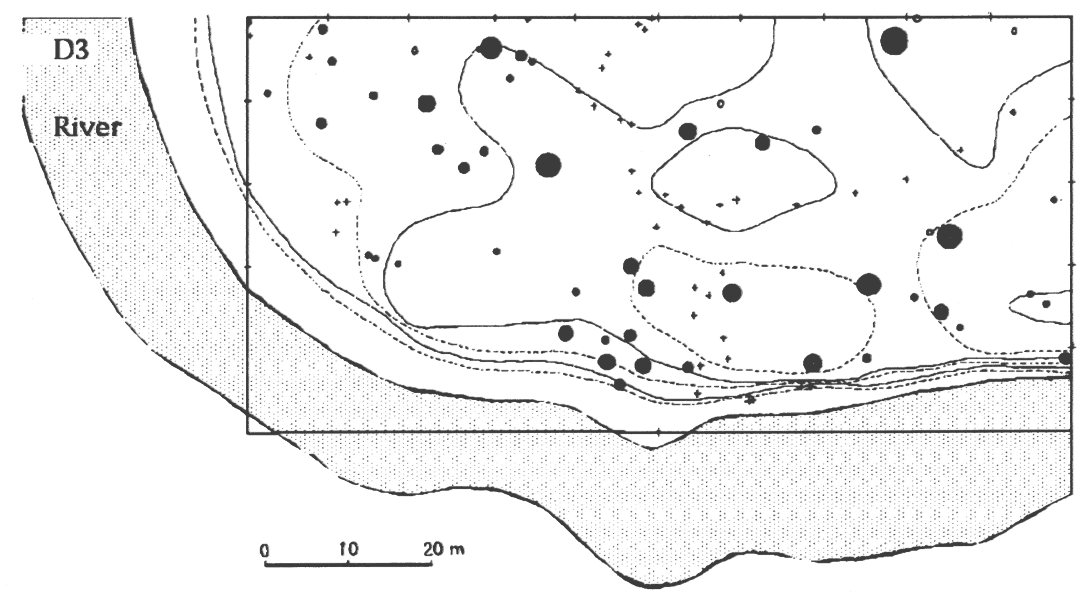

Fig. 11. Topography and location of trees in D-3. Contours of solid and broken line are at $1 \mathrm{~m}$ and $0.5 \mathrm{~m}$ intervals, respectively. $\mathrm{O}$ S. stenoptera. $\bigcirc$ : Other Dipterocarpaceae. +: Bullucia pentamera. The symbol size shows the tree size.

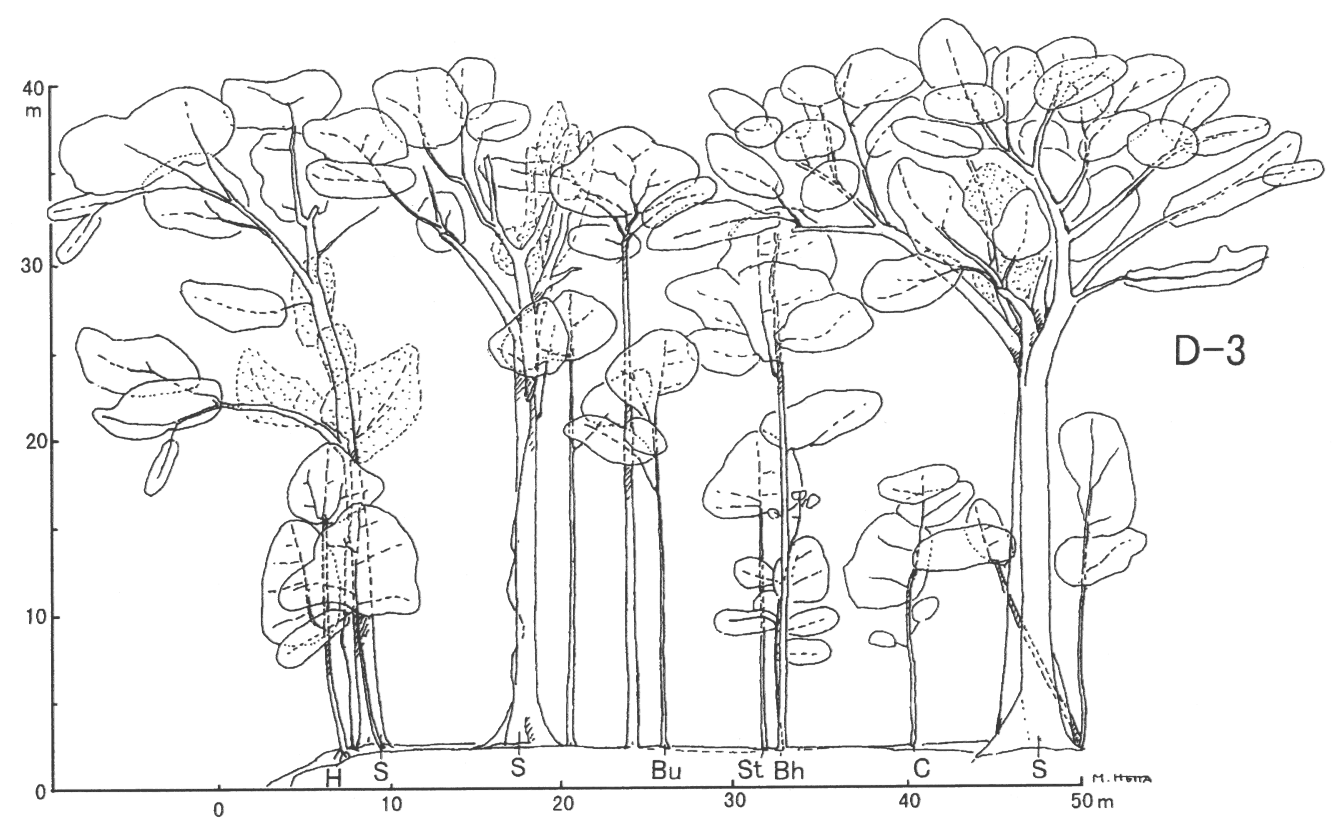

Fig. 12. Profile of D-3. Bh, Bhesa paniculata: Bu, Bullucia pentamera: C, Cleistanthus cf. myrianthus; $\mathrm{H}$, Horsfieldia (WK1328); St, Santiria tomentosa; S, Shorea stenoptera.

steep slope of a small mountain, and had 18 species of Dipterocarpaceae, such as Dryobalanops beccarii, Shorea laevis, S. leprosula, S. ovalis, S. pauciflora and Vatica micrantha but no $S$. stenoptera. The forest had a high diversity (Table 2).

\section{Soils in Daid}

Table 4 shows the result of soil analysis along the Daid River. The soil had been developed from two types of sandy materials. The first (Oxic Humitropepts and Aquic Dystropepts) was derived from the weathering of sandstone in most of D-1, and some part of D-2. The topography was undulating to rolling. The second was derived from loose sand produced by overflow on the flood plain along the 


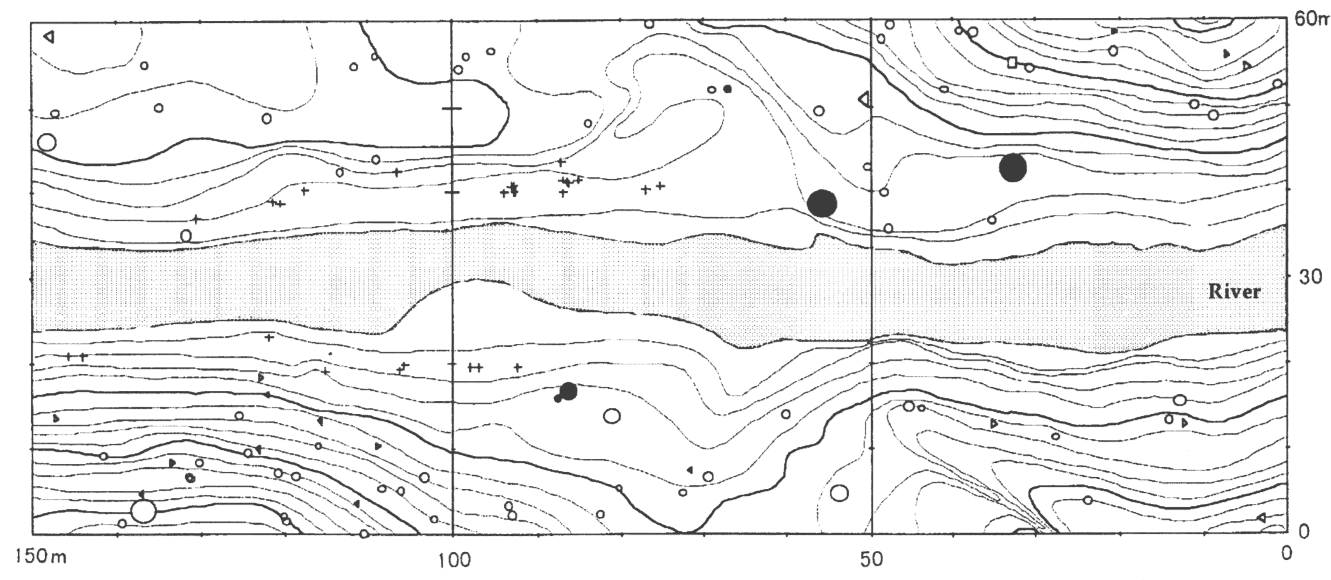

Fig. 13. Topography and location of trees in D-1. Contours are at $1 \mathrm{~m}$ intervals.

river in most area of D-3, and some parts of D-2.

Oxic Humitropepts was found on steep slope of D-1 and Aquic Dystropepts was on wet and gentle slope in D-1. Typic Dystropepts and Aquic Tropfluvents were found in flat area of D-3. The soil pH was weakly acidic or neutral (Table 4). The average clay content was 13.7 (SD=5.1)\%. Soils in D-3 had higher contents of sands than that in D-1. The carbon contents were low, about $1.5 \%$ to $1.1 \%$, and $\mathrm{CEC}$ was also low.

\section{Distribution of useful trees}

Many trees of tengkawang and Hevea brasiliensis were systematically planted in some forests in Ngabang and Muarailai. Tengkawang trees are native in this area, and they are planted in a large scale only at Ngabang. In Muarailai, their abundance might be increased by cutting of other species but most large trees seemed to germinate in natural. Tengkawang forest along the Daid River seemed to be in natural condition until recent. Hevea had been introduced from tropical south America and it is now the most important trees to make large plantation in this area. Because it can regenerate from seeds in and around the plantation, plots in Ngabang and Muarailai had many small Hevea trees. But the large seed without special equipment for dispersal rarely invaded natural forests. Other useful trees were also planted sporadically or often germinated from abandoned seeds after eating fruit. They were fruit trees in most case such as Lansium domesticum, Nephelium spp., Artocarpus integer, Baccaurea sp. and so on. Once they had been established in forest, they might regenerated naturally. A shrub species in Melastomataceae, Bullucia pentamera Naud., grew in open areas along rivers and made fruit of $3 \mathrm{~cm}$ in diameter with many fine seeds and apple like taste. It had been introduced from tropical Latin America, and was dispersed by animals and became and common shrubs in the study area. The specimens of this species collected from Java, Sumatra, Malaysia have been stored in Leiden. Though Whitmore (1991) mentioned that very few woody species from other region had become invasive and naturalized in perhumid tropical climates, Bullucia pentamera was one of the exceptional successes. In Durio of Bombacaceae, D. zibethinus is economically important species and commonly planted to make orchard, and a few trees were found in forests at nearly natural condition. D. kutejensis with red flower is also locally planted around Muarailai.

\section{Diversity of trees}

Four diversity indices were calculated for each plot (Table 2). The first index is Fisher's $\alpha$ 
Table 4. Physical and chemical characters of soil in the plots of Daid.

\begin{tabular}{|c|c|c|c|c|c|c|c|c|c|c|c|c|c|c|c|c|}
\hline \multirow[t]{2}{*}{$\begin{array}{l}\text { Pit Depth } \\
\text { No }\end{array}$} & \multirow[t]{2}{*}{$\begin{array}{l}\text { Hori- } \\
\text { zon }\end{array}$} & \multicolumn{3}{|c|}{ - Particle size (\%) } & \multicolumn{2}{|l|}{$\mathrm{pH}$} & Total & \multicolumn{3}{|c|}{$\begin{array}{c}\text { Total Sorption Coef. } \\
(\mathrm{mg} / 100 \mathrm{~g})\end{array}$} & \multicolumn{4}{|c|}{$\begin{array}{l}\text { Exchangable bases } \\
\text { (me/100g) }\end{array}$} & \multirow{2}{*}{$\begin{array}{l}\text { CEC } \\
(\mathrm{me} / 100 \mathrm{~g})\end{array}$} & \multirow{2}{*}{$\begin{array}{l}\text { Base Satu- } \\
\text { ration } \\
\text { degree } \\
(\mathrm{me} / 100 \mathrm{~g})\end{array}$} \\
\hline & & Sand & Silt & Clay & $\mathrm{H}_{2} \mathrm{O}$ & $\mathrm{KCl}$ & $\mathrm{C}(\%)$ & $\mathrm{N}(\%)$ & $\mathrm{P}_{3} \mathrm{O}_{5}$ & $\mathrm{~K}_{3} \mathrm{O}$ & $\mathrm{Ca}$ & $\mathrm{Mg}$ & $\mathrm{K}$ & $\mathrm{Na}$ & & \\
\hline \multicolumn{17}{|l|}{ D-1 } \\
\hline $10-13$ & A.1 & 63.8 & 10.9 & 25.3 & 5.9 & 4.6 & 2.41 & 0.075 & 14.49 & 3.52 & 0.16 & 0.24 & 0.23 & 0.18 & 5.72 & 14.16 \\
\hline $13-48$ & $\mathrm{AB}$ & 52.2 & 23.0 & 24.8 & 6.5 & 5.2 & 0.82 & 0.039 & 7.43 & 2.57 & 0.49 & 0.52 & 0.17 & 0.18 & 5.06 & 26.87 \\
\hline $48-97$ & B & 48.7 & 44.7 & 6.6 & 6.5 & 5.2 & 0.80 & 0.032 & 9.00 & 2.53 & 0.36 & 1.02 & 0.17 & 0.13 & 5.04 & 33.33 \\
\hline $97-133$ & $B C$ & 54.8 & 39.2 & 6.0 & 6.5 & 5.2 & 0.79 & 0.032 & 5.30 & 3.08 & - & - & - & - & - & - \\
\hline $2 \quad 0-6$ & A.1 & 85.3 & 1.0 & 13.7 & 6.6 & 5.3 & 1.26 & 0.041 & 9.18 & 2.51 & 0.31 & 0.31 & 0.12 & 0.04 & 4.79 & 16.28 \\
\hline $6-31$ & $\mathrm{AB}$ & 78.7 & 7.1 & 14.2 & 6.9 & 5.6 & 0.60 & 0.010 & 0.00 & 2.07 & 0.19 & 0.19 & 0.14 & 0.12 & 4.22 & 15.17 \\
\hline $31-56$ & B & 76.0 & 14.6 & 9.4 & 6.7 & 4.4 & 0.54 & 0.010 & 3.06 & 2.06 & 0.22 & 0.22 & 0.13 & 1.24 & 3.04 & 59.54 \\
\hline 56-107 & $B, g$ & 69.3 & 13.1 & 18.6 & 6.8 & 5.5 & 0.39 & 0.007 & 0.00 & 3.90 & - & - & - & - & - & - \\
\hline $3 \quad 0-9$ & A. 1 & 82.7 & 5.9 & 11.4 & 6.2 & 4.9 & 0.86 & 0.061 & 11.66 & 2.03 & 0.25 & 0.25 & 0.18 & 0.15 & 3.70 & 22.43 \\
\hline $9-22$ & $A B$ & 82.7 & 6.2 & 11.1 & 6.3 & 5.1 & 0.85 & 0.022 & 4.08 & 1.58 & 0.15 & 0.15 & 0.16 & 0.17 & 2.72 & 23.16 \\
\hline $22-42$ & B.1.1 & 89.5 & 2.4 & 8.1 & 6.7 & 4.6 & 0.83 & 0.028 & 0.00 & 1.59 & 0.04 & 0.04 & 0.13 & 0.12 & 2.35 & 14.04 \\
\hline $42-119$ & B.1.2 & 73.8 & 12.0 & 14.2 & 5.9 & 4.9 & 0.72 & 0.030 & 6.18 & 1.55 & - & - & - & - & - & - \\
\hline $119-145$ & RC & 72.2 & 14.3 & 13.5 & 6.5 & 5.2 & 0.47 & 0.052 & 3.09 & 2.03 & - & - & - & - & - & - \\
\hline $145-160$ & $\mathrm{CB}$ & 77.0 & 11.5 & 11.5 & 6.7 & 5.5 & 0.39 & 0.015 & 5.51 & 2.54 & - & - & - & - & - & - \\
\hline \multicolumn{17}{|l|}{ D-3 } \\
\hline $4 \quad 0-8$ & A.1 & 80.2 & 6.3 & 13.5 & 6.5 & 5.2 & 0.87 & 0.122 & 8.16 & 3.93 & 0.19 & 0.11 & 0.12 & 2.52 & 3.00 & 101.33 \\
\hline $8-23$ & C1 & 88.6 & 3.1 & 8.3 & 6.8 & 5.5 & 0.19 & 0.182 & 3.06 & 5.03 & 0.16 & 0.10 & 0.11 & 1.28 & 1.50 & 110.00 \\
\hline $23-46$ & $\mathrm{C} 2$ & 60.4 & 19.7 & 19.9 & 6.2 & 4.9 & 0.98 & 0.149 & 11.11 & 5.07 & 0.22 & 0.51 & 0.29 & 0.48 & 8.62 & 17.40 \\
\hline $46-71$ & C3 & 77.5 & 9.8 & 12.7 & 6.1 & 8.8 & 0.34 & 0.030 & 9.45 & 3.94 & - & - & - & - & - & - \\
\hline $71-86$ & C4 & 87.6 & 0.4 & 12.0 & 5.9 & 4.6 & 0.60 & 0.010 & 9.27 & 3.08 & - & - & - & - & - & - \\
\hline 86-112 & C5 & 73.9 & 9.6 & 16.5 & 6.4 & 5.1 & 0.19 & 0.035 & 12.24 & 3.91 & - & - & - & - & - & - \\
\hline $5 \quad 0-26$ & A. 1 & 79.9 & 6.7 & 13.4 & 6.3 & 5.0 & 1.48 & 0.111 & 18.36 & 6.03 & 0.12 & 0.22 & 0.17 & 2.15 & 3.09 & 86.08 \\
\hline 26-58 & C1 & 65.3 & 16.0 & 18.7 & 6.7 & 5.4 & 1.44 & 0.037 & 14.42 & 3.56 & 0.14 & 0.10 & 0.09 & 1.19 & 2.24 & 67.86 \\
\hline 58-98 & $\mathrm{C} 2$ & 75.6 & 12.4 & 12.0 & 6.7 & 5.5 & 0.78 & 0.087 & 15.60 & 3.93 & 0.17 & 0.10 & 0.10 & 2.24 & 3.37 & 77.45 \\
\hline $98-124$ & C3 & 92.1 & 0.6 & 7.3 & 6.9 & 5.6 & 0.78 & 0.016 & 6.12 & 3.06 & - & - & - & - & - & - \\
\hline
\end{tabular}

(Williams,1947),

$$
\mathrm{S}=\alpha \log _{\mathrm{e}}(1+\mathrm{N} / \alpha)
$$

where $\mathrm{N}$ and $\mathrm{S}$ is total number of individuals and species in plot, respectively.

The second is Morsita's $\beta$ (Morisita, 1967),

$$
\beta=1 / \Sigma(\mathrm{n}(\mathrm{n}-1) / \mathrm{N}(\mathrm{N}-1))
$$

where $\mathrm{n}$ is number of individuals of each species.

The third and fourth are Shanon-Weaver function (MacArthur \& MacArthur, 1961),

$$
\begin{aligned}
& \mathrm{H}_{(\mathrm{n})}^{\prime}=-\Sigma\left(\mathrm{n} \log _{2}(\mathrm{n})\right), \\
& \mathrm{H}_{(\mathrm{BA})}^{\prime}=-\Sigma\left(\mathrm{BA} \log _{2}(\mathrm{BA})\right),
\end{aligned}
$$

where $\mathrm{n}$ and BA are relative dominance of each species in number and BA, respectively. D-1 had the highest diversity. It had a complex topography, flat and steep river banks and a few open areas logged recently. Dipterocarp forest of D-4 on steep slope had diversity similar to D-1. The plot of $5000 \mathrm{~m}^{2}$ had 325 species of trees bigger than $4.8 \mathrm{~cm}$ in DBH. D-3 in natural forest of S. stenoptera had lower diversity and its Fisher's $\alpha$ was nearly 42 . Most area in this plot was flat river bank and exclusively dominated by $S$. stenoptera. The value was similar to those in $\mathrm{M}-3$ and $\mathrm{N}-1+2$. $\mathrm{M}-3$ seemed to be 
originated from natural forest of S. stenoptera and modified only a little. In 1-ha from N-1 to N-4, 123 species of 634 trees $(\mathrm{D}>4.8 \mathrm{~cm})$ was found, its diversity is much higher than natural forest in warm temperate zone. Most of the species was wild trees that might be remains of the lost natural forest. Though the lost forest might be a lowland dipterocarp forest, no Dipterocarpaceae was found except tengkawang and a tree of Dipterocarpus crinitus out of the plot. Dipterocarpaceae without seedbanks and the ability of vegetative reproduction might be extinct in this area though many other species survived.

\section{DISCUSSION}

\section{Habitat preference of tengkawang species}

In the tengkawang species of our study area, Shorea stenoptera was the most common and economically important species. It preferred sandy banks a few meter higher than the river water though it could grow on slopes if it had been planted such as plantations in M-1 (Fig. 7) or experimental forest at Haurbentes, Bogor. It became a large tree of $50 \mathrm{~m}$ height with light wood (Suzuki, unpublished data). It had the large leaf and fruit, and short fruit sepals. S. seminis preferred the same habitat with S. stenoptera but the former was less common. It made small fruits with short wings and is easily identified from its smaller leaves lepidote beneath. The fruits of both species with short sepals may be adapted to water dispersal (Suzuki \& Ashton, 1996). S. mecistopteryx, S. pinanga, and $S$. amplexicaulis grew on mountain slopes and had long fruit sepals. Out of our study site, $S$. macrophylla grew in a kerangas forest of Mandor (Fig. 1). It had similar leaf and fruit with $S$. stenoptera but a understorey tree of $20 \mathrm{~m}$ height and the trunk base were usually in water.

\section{History of use by European}

De Vriese traveled in West Kalimantan from October 1860 to early of 1861 (De Vriese, 1861; Van Steenis-Kruseman, 1948-1954), and found at first the tengkawang species: Shorea splendida (De Vriese) Ashton, S. stenoptera Burck, and S. seminis (De Vriese) Slooten. In 1886 Burck wrote a report of Mijyak tengkawang (fat of tengkawang) based on the collection by De Vriese. At that time, the Dutch knew the economic importance of tengkawang fat from West Kalimantan where were many small kingdoms under the control of the colonial government.

After the increase of demand for illipe nuts for export, the plantations of tengkawang were made at Ngabang which was the capital city of Landak Kingdom. Sanggau is one of the most important site of illipe nuts production and in the area of the natural distribution of S. stenoptera. But Sanggau was another small kingdom at that time. Landak Kingdom had natural habitat of S. stenoptera only in remote area such as the Daid River. For the convenience of transportation of hundreds tons of illipe nuts, Ngabang might be selected as plantation site, though it was probably out of natural distribution. Before recent construction of road, the most important transportation was boat. The Landak river between Ngabang to Pontianak is enough wide to transportation by boat though the Daid river is only a small stream as shallow as $0.5 \mathrm{~m}$ in most part.

\section{Traditional use of tengkawang and its effect on forest}

Before the study by Dutch in middle of the 19th century, people in West Kalimantan had known the value of tengkawang and used them. They had changed the forests by cutting woods and planting of useful trees such as Durio, Artocarpus, Lansium and tengkawang. Even a introduced species from Latin America, Bullucia pentamera, spread at open sites along rivers in natural forest areas. $S$. 
stenoptera prefers the habitat of flat and sandy river banks. Because these sites were also suitable place to make villages, $S$. stenoptera was easily affected by human activity. The people often changed the location of their settlements. Thus the forests, which were distant from villages of today and looked like natural ones, might be affected by people in old time. Then the S. stenoptera forests in Daid and Muarailai have the possibility of plantations older than the plantation at Ngabang. The canopy trees of S. stenoptera in Daid and Muarailai were larger than those in plantation in Ngabang and looks older than the latter. The former seemed to have germinated before the start of export in late 19 th century.

But we think that the possibility of plantation before the late 19th century is very low from the following reasons. One of the reason is that the demand of illipe nuts to home use seemed to be low before the start of export, and is nearly zero today. The production of fat from tengkawang is time consuming work and is not preferred by people. According to people at Muarailai and Ngabang, the traditional way of making fat from illipe nuts of Dayak is as follow: 1) take the wings and seed coat and dry the embryo, 2) crash them, 3) put them into bamboo, 4) heating the bamboo with fire, and 5) turn the bamboo and melted fat flow down. They said also that this method was inefficient to get fat, and no one wanted to make fat after coconuts oil became available. Then the fat of tengkawang was rarely found in the village where the illipe nuts were harvested. The second reason is that the Shorea species make fruit only one time in several years. If people want to use the fat every day they must make a big stock at the fruiting season. The third reason is that the fat can be also made from many other Shorea species though S. stenoptera is preferred as the source because the big production of large fruit. The enough amount of nuts for the family use might be available from forests of many Shorea species around villages. The fourth reason is that the distribution is far from villages existed for long periods. For example Serimbu, the central village of the area of Daid River for hundreds years, had only a few trees of $S$. stenoptera though there are many river banks suitable for $S$. stenoptera growth around Serimbu. From above reasons, the value of tengkawang as the source of fat for local people was not so great to promote to make the plantation before the start of export. Therefore we consider that the tengkawang forests in Daid was natural. The S. stenoptera forest in Muarailai changed partly by human activity but the most big trees were germinated naturally.

\section{Tengkawang forests of today}

Tengkawang trees such as S. stenoptera, S. pinanga, and S. amplexicaulis can make forests of $50 \mathrm{~m}$ in height and a large biomass. The old plantation also had rather high species diversity though the flora might be biased a little. These value are much higher than the rubber tree (Hevea brasiliensis) and oil palm (Elaeis guineensis Jacq.) plantations which are planted most frequently in West Kalimantan. And tengkawang species are native trees though rubber tree and oil palm were introduced species from Latin America and Africa, respectively. It can serve the economic benefit from the fruit, though it fruits only a time in several years. Then the tengkawang forests have the possibility to keep the forest biomass, biodiversity and economic needs. The economic value of the illipe nuts was, however, much lower than rubber plantation or shifting cultivation because of its character of rare fruiting. Then many tengkawang forests were suffered to be logged or burnt in spite of its protection by law. The tengkawang plantation of M-1 was changed into shifting cultivation in 1992, many trees in D-2 and D-3 were logged. Then we abandoned the remeasure in these plots. The old plantation in Ngabang may be sold for logging because the owner can get few benefit from the nuts. We need more strong control to protect the tengkawang forests, and also need to increase the commercial value of illipe nuts in the global market. 
ACKNOWLEDGMENTS We are grateful to LIPI and PHPA for the permission of cooperative researches with staff of Puslitbang Biologi (No.: 3920/V.3/KS/1991, No.: 6356/II/1922, No.: 5032/II/KS/1933, No.: 3670/II/KS1994). We got a lot of support from P. T. Batasan during the study in Daid and Muarailai. We thank Mr. Gusti Basuni Bdr. and his family for the study in their plantation at Ngabang. Our field works could not be done without helps of many assistants. This study was financially supported by International Scientific Research Program (No. 03041064) from Ministry Education, Science and Culture, Japan.

\section{REFERENCES}

Ashton, P. S. 1982. Dipterocarpaceae. Flora Malesiana 9 (2): 237-552.

Burck, W. 1886. Minjak tengkawang en andera Weinegg bekende Plantaardige Vetten In Nederlandsch-Indie. Mededeelingen Uit 'Slande Plantentuin. III. Batavia Landsdrukkerij, 1-45.

Departmen Kehutanan 1996. Kebun Percobaan (Experimental forest). 29 pp. Pusat Penelitian dan pengembangan Hutan Bogor.

De Vriese, W. H. 1861. Minjak tagkawang, en andere voortbregselen van het plantenrijk van Borneo's wester-afdeeling, welke aanbeveling verdienen voor den Nederlandschen handel. 57pp. Leiden, A. W. Sythoff.

Hotta, M., Ogata, K., Nitta, A., Hosikawa, K., Yanagi, M., \& Yamazaki, K. (ed.) 1989. Sekai YuhyoShokubutu Jiten (Useful plant of the World). Heibonsha,Tokyo. 1499 pp.(in Japanese)

MacArthur, R. H. \& MacArthur, J. W. 1961. On bird species diversity. Ecol., 42: 594-598.

Morisita, M. 1967. Seasonal distribution of butterfly around Kyoto. In: Morisita, M \& Kira, T., eds., Natural History Ecological Studies, 95-132. Chuokoron-sha, Tokyo. (in Japanese)

Sastrodimedjo, S., Soediono, Y., Poedianto, M., Soekarno, M. K., Prodjosoetardjo, S., Mardjuki, A., Roedjai, Wiroatmodjo, P., Abdoellah, Hadisasmito, S., Soeradji, I., \& Yoesoep, O. 1974. Survey Report on the S. Landak - S. Tayan Forest Complex, Province of West Kalimantan. Directorate of Forestry Programming, $30 \mathrm{pp}$.

Soon, W. 1988. The Chocolaty Fat from the Borneo Illipe trees, 222 pp. Vivar Printing, Malaysia.

Sumadiwangsa, S. 1977. Biji Tengkawang Sebagai Baku Lemak Nabati (Tengkawang kernels as raw material for vegetable fat). Laporan 91:1-24. Forest Product Research Institute (LPHH), Bogor.

Suzuki, E., \& Ashton, P. S. 1996. Sepal and nut size ratio of fruits of Asian Dipterocarpaceae and its implication for dispersal. J. Trop. Ecol. 12:853-870.

— \& Gadrinab, L. U. 1988. Fruit production of a six-year old Shorea stenoptera plantation at Haurbentes, Bogor, Indonesia. BIOTROPIA 2:1-7.

Team Penyusun Monografi Daerah Kalimantan Barat. 1976. Monografi Daerah Kalimantan Barat (Monograph of West Kalimantan). Departmen Pendidikan dan Kebudayaan RI Direktorat Jenderal Kebudayaan Jakarta. 64pp. (in Indonesian)

Van Steenis-Kruseman, M. J. 1948-1954. Special part (Cyclopedia of Collector). Flora Malesiana , ser. 1, 1:1-639 (p.552)

Watanabe, H. 1996. On Tengkawang (Illipe nut) produced in Borneo. Tropical Forestry 35:14-21.(in Japanese)

Whitmore, T. C. 1991. Invasive woody plants in perhumid tropical climates. In: Ramakarishnan, P. S., ed., Ecology of Biological Invasion in the Tropics, 35-40.

Williams, C. B. 1947. The logarithmic series and its application to biological problems. J. Ecol., 34: 253-272.

Received March 27, 1997

Accepted July, 10, 1997 
鈴木英治, 堀田 満, Tukirin PARTOMIHARDJO, Achmad SULE, 小池文人, 野間直彦, 山田俊弘, 梶 幹男さまざまな管理下にある西カリマンタンのテンカワン林の生態

西カリマンタンのフタバガキ科のShorea 属の中には, テンカワンと呼ばれ, 果実から油脂がとれ, 経済的 に有用な樹種が約 10 種類ある。果実は天然林・半天然林および植林から採集されてきた。このような人間 の活動によってテンカワン林がどのように変化したかを研究するために, 1991 年に 8 つ調査地を設定し た。かってのランダック王国の首都であったンガバンでは, それぞれ約 $1 \mathrm{~km}^{2}$ のテンカワン植林が, 約百 年前に王家によって, ランダック川沿いに2つ作られた。テンカワンの代表的な種であるShorea stenoptera は, 自然の立地に似た川の近くの平坦な堤防に, S. amplexicaulis とS. pinanga などは斜面に植えられた。 それらは胸高直径 (DBH) $125 \mathrm{~cm}$ 樹高 $49 \mathrm{~m}$ に達し, 1991 1994 年の平均直径成長速度は $0.28( \pm 0.32 S D)$ $\mathrm{cm} /$ 年であった。パラゴム Hevea brasiliensis は平坦地に, 昔ゴム生産に使われたPalaquium gutta は斜面 に, テンカワン下層木として栽培されていた。1ha の調査地内に DBH $4.8 \mathrm{~cm}$ 以上の樹木が 123 種あり, テンカワン天然林と大差ない多様性を持っていた。

ムアライレイ村近くの小さな川沿いの堤防の上に, 半自然状態の最大 DBH $186 \mathrm{~cm}$ に達するテンカワン 林があった。元は天然林と思われるが不要な木を伐採し, パラゴムやドリアンなどをテンカワンの間に植 栽していた。

ランダック川支流のダイド川沿いには, ほぼ自然状態のテンカワン林があった。森林構造は半自然林と 似ているが，南米原産で冕出帰化したBullucia pentamera が見られる他は栽培種はなかった。平坦な砂質 自然堤防上のテンカワン天然林では, S. stenoptera が胸高断面積合計の8 割を占めるので, 斜面のフタバ ガキ天然林よりずっと多様性が低かった。 